\title{
Rethinking the Role and Architectural Value of the St. Andrew Kim Dae-Geon Memorial Church in the Mirinae Shrine in Korea
}

\author{
Myengsoo Seo
}

Citation: Seo, Myengsoo. 2021. Rethinking the Role and Architectural Value of the St. Andrew Kim DaeGeon Memorial Church in the Mirinae Shrine in Korea. Religions 12: 919. https://doi.org/10.3390/ rel12110919

Academic Editor: Iakovos Potamianos

Received: 17 August 2021 Accepted: 15 October 2021 Published: 22 October 2021

Publisher's Note: MDPI stays neutral with regard to jurisdictional claims in published maps and institutional affiliations.

Copyright: (C) 2021 by the author. Licensee MDPI, Basel, Switzerland. This article is an open access article distributed under the terms and conditions of the Creative Commons Attribution (CC BY) license (https:// creativecommons.org/licenses/by/ $4.0 /)$.
School of Architecture \& Design Convergence, Hankyong National University, Anseong 17579, Korea; seomyeng@gmail.com or seoms@hknu.ac.kr

\begin{abstract}
This paper reconsiders the role and value of the St. Andrew Kim Dae-Geon Memorial Church and his grave site in the Mirinae Shrine, currently recognized as a special place of pilgrimage for Catholics in Korea. The Mirinae area is the place where the remains of Father Kim Dae-Geon were relocated after his martyrdom in 1846. To commemorate this, the St. Andrew Kim Dae-Geon Memorial Church was built in 1928 by his grave, and his relics and image are enshrined within. This research examines the value of the church and his grave site from three perspectives: first, the historical value related to Father Kim Dae-Geon; second, the architectural value of the Memorial Church; and third, value from the sense of place (or genius loci) of the church and environs. The role and architectural value of the building and site were examined through a literature review, an archival investigation, and a visit to the site. This research is about interpretation of the church and Father Kim Dae-Geon's grave site in the Mirinae Shrine-not only the building itself, but also its sense of place, beyond the historical research focusing on the person.
\end{abstract}

Keywords: Mirinae Shrine; St. Andrew Kim Dae-Geon; Catholic Church; modern age; sites of memory

\section{Introduction}

\subsection{Background and Purpose}

In the Mirinae Shrine, the grave and memorial church to Korea's first priest and martyr, St. Andrew Kim Dae-Geon, are located. It is recognized as a key pilgrimage site for Catholics, and pilgrims continuously visit. This research is aimed at rethinking the role and value of the St. Andrew Kim Dae-Geon Memorial Church (hereafter the "Memorial Church") and his grave site in the Mirinae Shrine.

St. Andrew Kim Dae-Geon (21 August 1821-16 September 1846) is Korea's first priest and martyr, and was canonized. He was born in Solmoe Dangjin (currently Songsan-ri, Woogang-myeon, Dangjin-gun, Chungnam) on 21 August 1821. He was ordained as a priest in Shanghai, China, on 17 August 1845, and returned to Korea through Ganggyeong Nabawi (currently Hwasan-ri, Mangseong-myeon, Iksan-si, Jeonbuk) on 12 October 1845. Subsequently, he carried out pastoral activity, centered on Ini Catholic Church (called Gongso) in Yongin. ${ }^{1}$ While he was exploring a new sea route for the arrival of missionaries, he was arrested and martyred in the Senamteo of Hangang River execution ground (currently Icheon-dong, Yongsan-gu, Seoul) on 16 September 1846. He was just 25 years old, and had only been a priest for 13 short months after he had been ordained. After he was executed, his body was buried in Waseo (currently 3-ga, Yongsan-dong, Yongsan-gu, Seoul), and his remains were relocated to the Mirinae Shrine (currently 141, Misan-ri, Yangseong-myeon, Anseong-si) ${ }^{2}$ by Lee Min-Shik (Vincentius) 40 days after his martyrdom. Later, Father Kim Dae-Geon was beatified ${ }^{3}$ by Pope Pius XI (1857-1939) on 5 July, 1925, and was granted the title of the Blessed. 
The Korean Roman Catholic Church completed the construction of the "Blessed Memorial Church (福者記念聖堂)" at the site where Father Kim Dae-Geon's grave was located in line with beatification in July 1928, and Bishop Larribeau [Korean name 元亨根， Won Hyung-Geun (Andriano)] performed oblation and consecration ${ }^{4}$ on 18 September 1928. Inside the church, some of his bones and some pieces of the coffin that contained his body were enshrined; his spirit and faith have long been admired. ${ }^{5}$ From the historical perspective of the Korean Catholic Church, the Memorial Church and his grave site within the Mirinae Shrine has significant meaning: The shrine is centered on Father Andrew Kim Dae-Geon and the graves of other priests who played a key role in Korean Catholic Church history such as Father Mark Kang Do-Young, Bishop Jean Joseph Ferréol, and Father Peter Choi Moon-Shik. Moreover, the remains of Father Kim Dae-Geon's mother Ko Ursula, and Lee Min-Shik (Vincentius), who transferred the body of Father Kim Dae-Geon to Mirinae after he had been killed, are located here as well. Therefore, the venue is of immense value.

This study examines the historical significance of Mirinae Shrine, which played a central role in the religious community during the full-fledged oppression of Catholicism in Joseon Korea starting in the late 19th century, focusing on Father Kim Dae-Geon. Moreover, this research explores the role and architectural value of St. Andrew Kim Dae-Geon Memorial Church, which was constructed in a modern architectural style during the Japanese colonial period in the early 20th century in Korea. This research illustrates the value of churches built in the early modern age in Korea, encompassing the Memorial Church and his grave site in the Mirinae Shrine, the sense of place or genius loci, and its architectural value from various viewpoints.

\subsection{Method and Procedure}

This paper explores the value of Father Kim Dae-Geon's grave site and Memorial Church through primary methods such as literature review, archival investigation, and a field trip. I have investigated the archive of the missionaries of the Paris Expeditionary Church and the letters of Father Kang Do-Young, the first provost of the Memorial Church. ${ }^{6}$ I also refer to the records of believers, such as Memorandum of beatification for the martyrs of Gihae (1839) and Byeongoh (1846), and church press articles including Gyeonghyang Magazine. Papers including the Suwon Research Institute of Catholic History in 2008 and those that revised and supplemented the statement of academic symposium organized by the Mirinae Shrine are also used (Jung 2008, pp. 7-46; Cha 2008, pp. 209-34; Lee 2008, pp. 235-82). The relevant details in 50 Years of History of Suwon Parish: 1853-2013. I. History of Parish translated and footnoted by the Suwon Research Institute of Catholic History are also referred to (Suwon Research Institute of Catholic History 2017).

This research examines three aspects of the importance of the Memorial Church and his grave site. First, in the context of the historical importance of the Memorial Church, it considers the Memorial Church and Father Kim Dae-Geon's crucial key role in the establishment of Korean Catholicism. Second, regarding the architectural importance of the Memorial Church, the study investigates the evaluation of the architectural importance from a different perspective than existing large churches. Third, the importance of the sense of place (genius loci) of the Memorial Church and the grave site are considered; they have played a key role as a venue for memories for the pilgrims visiting the area since the completion of the Memorial Church. 


\section{St. Andrew Kim Dae-Geon Memorial Church and His Grave Site}

\subsection{From the Blessed Memorial Church to the St. Andrew Kim Dae-Geon Memorial Church}

When the establishment of the church was discussed in 1921, the Memorial Church's original name was “The Blessed Memorial Church (福者記念聖堂)". The Blessed was a term referring to Father Kim Dae-Geon, and he was canonized by Pope John Paul II in 1984. The Blessed Memorial Church was built in 1928 to commemorate (顯揚 $)^{7}$ the martyrdom of Father Kim Dae-Geon and to serve an oratorium dedicated to pilgrims. In the first image of the church, there was a stele with "the Blessed Memorial Church" inscribed on it at its entrance. The inscription was later changed to the "Memorial Oratory for 79 Blessed Korean Martyrs (79위 시복 기념 경당)" (see Figure 1). On 2 November 2020, Suwon parish changed the name again to "St. Andrew Kim Dae-Geon Memorial Church" (Lee 2020; Jung 2020; Baek 2020).

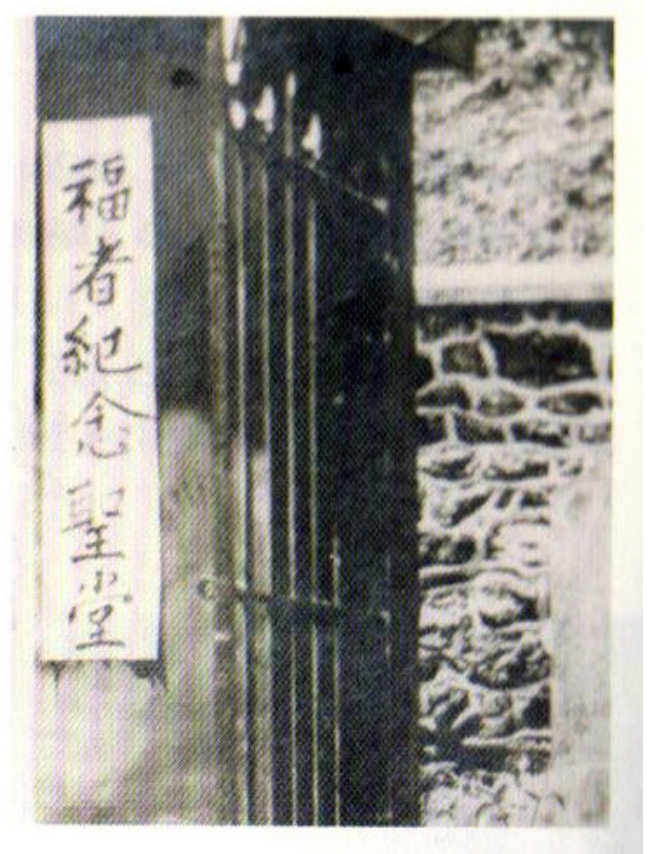

Figure 1. Stele at the initial church entrance [source: Father Kang Do-Young's Collection of Letters, p. 568].

Originally "oratorium" is a term deriving from Latin meaning "space for prayer". It is a compound of the term "orare", which means to pray, and "rium", which is a suffix for places. Architecturally, the word denotes a house or church dedicated to the purpose of worshipping God. "Oratory" means a small place for prayer and means the small church of an individual or institution. ${ }^{8}$ It is not a church for general believers but for a specific group. Oratoriums can vary depending on who they are open to: an oratorium publicum allows believers from the general public to participate when there is a mass or ceremony; and an oratorium semi-publicum is one which is limited to general believers. ${ }^{9}$ If an oratorium is only for an individual or their family, it is called an oratorium privatum. ${ }^{10}$

Discussions on the construction of the Memorial Church among priests started in 1921. During a Korean priests' retreat held during 5-9 May 1921, the construction of a memorial hall to exalt Father Kim Dae-Geon was decided upon and discussion of the issue of raising funds began (Cha 2008, p. 225). During the retreat held the next year (15 May 1922), these issues were discussed again, and there was also discussion of where to build the Memorial Hall (Cha 2008, p. 225). ${ }^{11}$

"Some priests in Hwanghae-do said to me, "Why should the Memorial Hall be built in a rural area, Mirinae? It would be better to build it in Yongsan (Senamteo), as it would be easier to worship, regarding the construction of the Memorial 
Hall at the old grave site of the martyr Father Kim Dae-Geon". I said to them, "I [Kang Do-Young] do not intend to build it in Mirinae and do not force to donate promised money to pay last year. The money donated by some priests was left to the bookkeeper, and whether it should be located in Mirinae or Yongsan depends on the will of bishop."'" (Kang 2016, pp. 210-11; emphasis added) $)^{12}$

The role of provost Father Kang Do-Young (1863-1929), who was assigned to be the provost in Mirinae, was crucial for the construction of the Memorial Church (Kang 2016; Cha 2008, pp. 209-34; Oh 1961, pp. 40-50). He was strongly committed to building the Memorial Hall in Mirinae. As the venue to build the Memorial Hall, Yongsan (Senamteo) and Mirinae areas were discussed, and Father Kang Do-Young recommended building it in Mirinae.

"Rather than Senamteo, where [Father Kim Dae-Geon] was killed, we should build the Oratorium in Mirinae, where he has been buried for 55 years (1846-1901)

... Bishop Go's grave is here as well and the Oratorium should be built in Mirinae to commemorate the passion of the Mirinae Shrine people who brought the body of Father Kim Dae-Geon there." (Oh 1961, p. 47; Cha 2008, p. 210; emphasis added)

Father Kang Do-Young received a positive response from many priests on the construction of Memorial Hall. The leaders in Mirinae supported his proposal by raising the funds required to build the Oratorium in the holy month of the Martyr for the first Feast for Korea's Chimyeong Blessing of 79th on 26 September 1926 (Catholic Bishops' Conference of Korea 1927, p. 203; Oh 1961, p. 49; Cha 2008, p. 226). With internal and external help, Father Kang Do-Young received formal permission for the construction of the Memorial Hall from Bishop Devred and prepared a construction plan (Cha 2008, p. 226). The decision to begin construction was made in 1927, and it began in spring of 1928, 3 years after the beatification ceremony of the 79 martyrs was held on 5 July, 1925, with completion in July 1928. The benediction ceremony of the Memorial Oratorium construction in the Misan-ri Shrine in Anseong was held with Assistant Bishop A. Larribeau (Andriano) officiating on 18 September 1928 (Kang 2016, p. 561). An article in The Dong-A Ilbo dated 5 October 1928 reported that a church honoring Korea's first priest, St. Andrew Kim Dae-Geon Memorial Church (1928), had been built and hundreds of believers gathered on 18 September 1928 for the dedication and inauguration ceremony (see Figure 2).

"Since Catholicism was introduced in Korea, there were many martyrs due to the brutal killing of believers. To honor them, a beatification ceremony was held for 79 martyrs, whose pilgrimage achievements and values can be attested to, to award them the title of the Blessed. This is not only an honor for the Korean Catholic Church but also a model expression of the Korean People's brave spirit and faith. . ... Among the blessed martyrs, the person with the most special achievements is Father Kim Dae-Geon. The church built around his grave was called the Blessed Memorial Church and so it became a permanent holy worship hall for Korean Catholic believers." (The Dong-A Ilbo 1928, p. 4; emphasis added) 


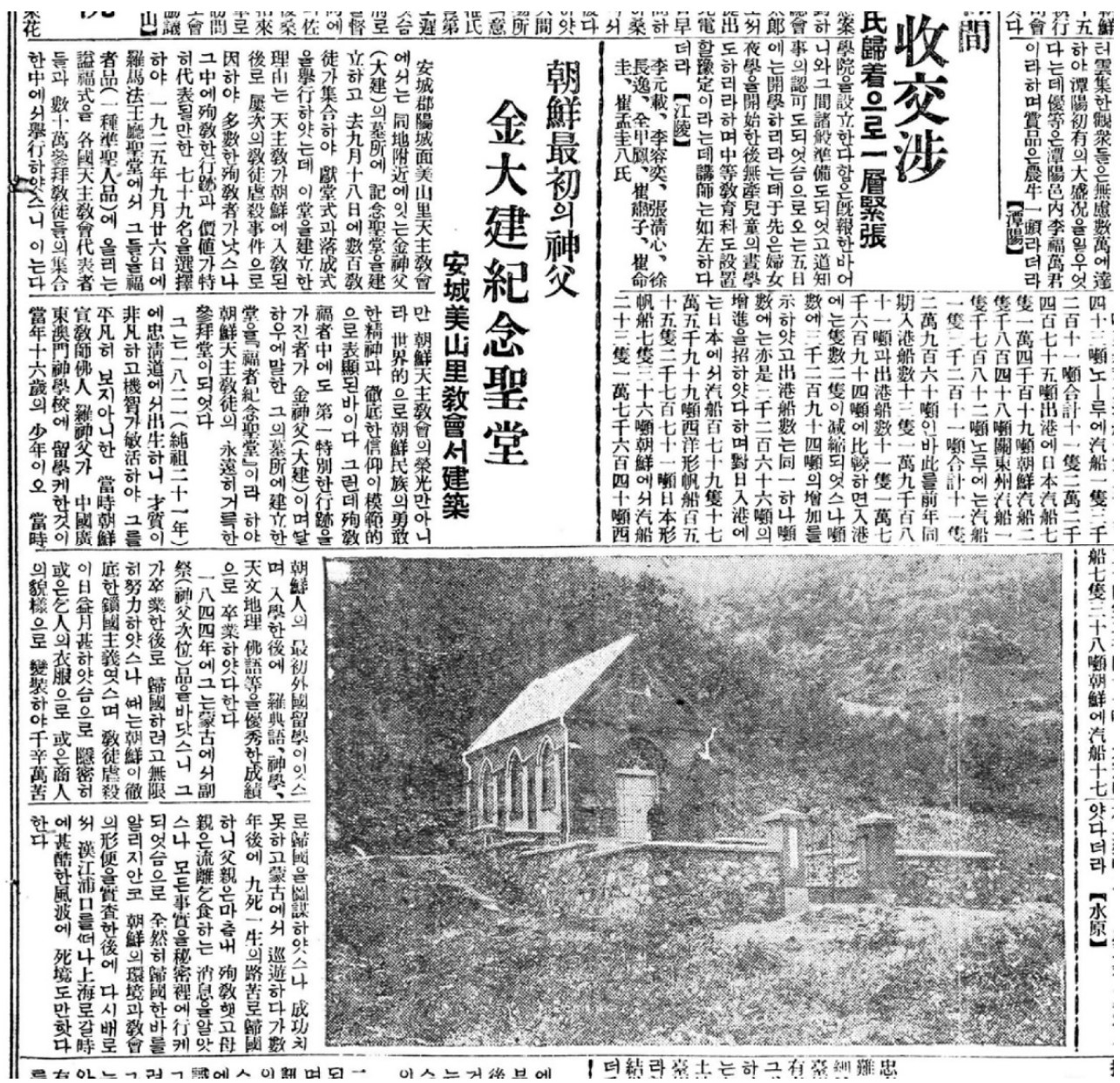

Figure 2. Article on the newly built St. Andrew Kim Dae-Geon Memorial Church [source: The Dong- $A$ Ilbo, 5 October 1928].

\subsection{Father Kim Dae-Geon's Grave and Surrounding Other Graves}

In the site around Father Kim Dae-Geon's grave and other graves on the left in front of the Memorial Church, he and other Catholic believers are buried, including the priests who played a key role in Korean Catholic Church history (see Table 1). In front of the Memorial Church, from left to right, there are the graves of Father Mark Kang Do-Young (1863-1929), Father Andrew Kim Dae-Geon (1821-1946), Bishop Jean Joseph Ferréol (1808-1853), and Father Peter Choi Moon-Shik (1881-1952). On the left side of the Memorial Church, the grave of Father Kim Dae-Geon's mother, Ko Ursula (1798-1864), is located (see Figure 3).

Father Mark Kang Do-Young was born in Seoul and studied at Penang Seminary from 1883 until 1892. After returning to Korea, he was transferred to Yesu Seongsim Sinhakgyo (Holy Seminary of Jesus Christ in Yongsan), now the College of Theology at the Catholic University of Korea. As the first provost of the Mirinae Church, he was Korea's third priest alongside Jung Gyu-Ha (1863-1943) and Kang Sung-Sam (1866-1903). He was the first priest to receive ordination in Korea on 26 April 1896, and was in charge of pastoral activities for over 30 years until his death, having by then been assigned to be the first provost of the Mirinae Church. He established St. Joseph's Church and founded Heasung Hakwon, the second elementary school in Anseong. He promoted the construction of the Memorial Church (Cha 2008, p. 209). Father Kang Do-Young passed away on 12 March 1929, and buried in Mirinae Shrine. 
Table 1. History of the Memorial Church and the Surrounding Areas of Graves ${ }^{13}$.

\begin{tabular}{|c|c|}
\hline Date & Details \\
\hline 5-8 May 1921 & Decision to build a Memorial Hall to exalt Father Kim Dae-Geon during the Korean priests' retreat. \\
\hline 15 May 1922 & $\begin{array}{c}\text { As the issue of building St. Andrew Kim Dae-Geon Memorial Hall was discussed once more during the } \\
\text { Korean priests' retreat, opinions on where to build it were exchanged. }\end{array}$ \\
\hline July 1928 & The Blessed St. Andrew Kim Dae-Geon Memorial Oratorium is completed. \\
\hline 18 September 1928 & $\begin{array}{l}\text { The above Memorial Oratorium is dedicated as the "Korean martyrs' Our Lady of Angels Memorial } \\
\text { Oratorium" with Bishop Larribeau officiating. The Memorial Oratorium becomes the Korean Catholic } \\
\text { Church's representative martyrs' exaltation pilgrimage memorial oratorium. }\end{array}$ \\
\hline 12 March 1929 & Father Kang Do-Young dies, and his body is buried near Father Kim Dae-Geon \\
\hline 11 October 1952 & $\begin{array}{l}\text { The third provost of Mirinae Church Father Peter Choi Moon-Shik dies and his body is buried near Father } \\
\text { Kim Dae-Geon. }\end{array}$ \\
\hline 5 July 1960 & $\begin{array}{l}\text { The bones of the extremities (toe bones) and coffin pieces of the Blessed Father Kim Dae-Geon are buried in } \\
\text { the Memorial Oratorium. The other remains are buried in Daeshin Seminary in Hyehwa-dong, and later } \\
\text { transferred and buried in the Martyrs Memorial Hall of Jeoldusan. }\end{array}$ \\
\hline 26 September 1965 & $\begin{array}{l}\text { The remains of Ko Ursula and Lee Min-Shik are transferred from below the Memorial Oratorium to their } \\
\text { present site outside and a plaza is constructed there. }\end{array}$ \\
\hline 26 September 1976 & $\begin{array}{c}\text { Foreign bishops visit Korea to participate in the Far Eastern Bishops' the Blessed Exaltation Convention held } \\
\text { to mark the 130th anniversary of Father Kim Dae-Geon's martyrdom. Korean bishops jointly officiate the } \\
\text { exaltation mass. On the same day, the unveiling ceremony of the marble statue of Father Kim } \\
\text { Dae-Geon is held. }\end{array}$ \\
\hline 6 May 1984 & $\begin{array}{c}\text { Canonization of the } 103 \text { martyrs, the Blessed including the Blessed Father Kim Dae-Geon-celebrant: Pope } \\
\text { John Paul II. }\end{array}$ \\
\hline 2009 & $\begin{array}{l}\text { The Catholic Suwon Parish Maintenance Foundation presents a Cultural Asset Registration Application Form } \\
\text { for cultural heritage conservation according to state-designated cultural asset registration of Father Kim } \\
\text { Dae-Geon's grave, St. Andrew Kim Dae-Geon Memorial Church, and St. Joseph's Church. }\end{array}$ \\
\hline 2013 & $\begin{array}{l}\text { The Mirinae Shrine Development Committee applies for the Registered Cultural Properties of the Memorial } \\
\text { Oratory for } 79 \text { Blessed Korean Martyrs and the area surrounding Father Kim Dae-Geun's grave. }\end{array}$ \\
\hline 2 November 2020 & $\begin{array}{l}\text { The Catholic Suwon Parish changes the name of the } 79 \text { Korean Martyrs Beatification Memorial Oratorium to } \\
\text { St. Andrew Kim Dae-Geon Memorial Church. }\end{array}$ \\
\hline
\end{tabular}

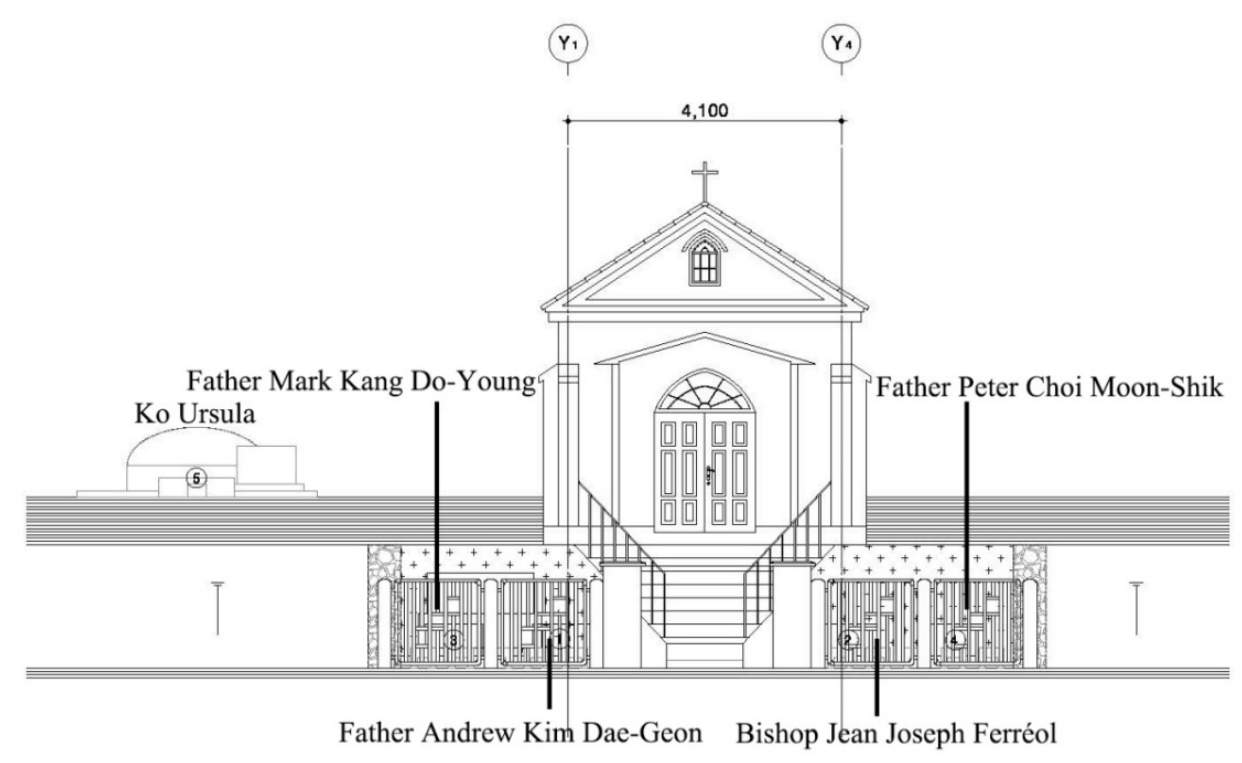

Father Andrew Kim Dae-Geon Bishop Jean Joseph Ferréol

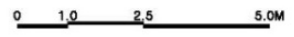

Figure 3. Elevation drawing of the Memorial Church [source: drawing by Heewoo Architecture and Conservation Architects. Co., Ltd.]. 
Bishop Jean Joseph Ferréol, the third diocesan of Joseon, was the teacher of Father Kim Dae-Geon. Bishop Ferréol ordinated Father Kim Dae-Geon as a deaconate in December 1844 and ordained him as a priest on 17 August 1845. Bishop Jean Joseph Ferréol expressed his desire to be buried beside Bishop Laurent Marie Joseph Imbert (Korean name 范世亨, Beom Se-Hyung) or Father Kim Dae-Geon (Jung 2008, p. 20; Dallet 1980, p. 198). Following Bishop Ferréol's will, he was buried beside Father Kim Dae-Geon.

Father Peter Choi Moon-Shik, who received his ordination as a priest in 1910, was assigned as the parish priest of Choyangha Catholic Church in Paldo, North Gando Area, and was a pioneer of parish activities for overseas Koreans. After being assigned as the third provost of Mirinae Church in 1932, he performed pastoral activities for 20 years until he passed away on 11 October 1952 (Catholic Suwon Parish Maintenance Foundation 2009).

\section{Architectural Features and Preservation of the Memorial Church}

\subsection{Architectural Features of the Memorial Church}

In July 1928, the Blessed Memorial Church was completed with dimensions of $8 \mathrm{~m}$ (about 26 chuck) in width and $4 \mathrm{~m}$ (about 13 chuck) in length (see Figure 4). On 20 October 1928, details about the Memorial Church were presented in the Supplementum Tabella SS. Cordis Jesu (Kang 2016, p. 571). ${ }^{14}$ The Tabella was a monthly magazine published by Yongsan Jesus Sacred Heart Theological Seminary read by Korean clergymen from June $1912 .{ }^{15}$ The Tabella Supplementum consisted of the combined writings of many theology students, and it is not clear which theology students wrote about the Memorial Church. One account by a theological student who observed the construction contained a simple image of the church as it was being built. Upon looking at the details, it can be seen that the church was built by Chinese laborers and concrete (洋灰) was used as construction material for the building. The graves of Father Kim Dae-Geon and that of Bishop Jean Joseph Ferréol were all finished with concrete. Not only the oratorium, but the interior as well, was built with concrete. Around the graves, reinforcing stone walls, about $2 \mathrm{~m}$ in height, were built to mark the boundary.

"I came to Mirinae 15 days ago, and I plan to stay here until this weekend. I saw Chinese were building the Blessed St. Andrew Kim Dae-Geon Memorial Oratorium.

The oratorium was completed last Saturday. Now they are building walls around the oratorium. The oratorium and altar stone were made with concrete. The grave for the Martyrs will be made with concrete like the grave of Bishop Jean Joseph Ferréol who ordinated the Blessed St. Andrew Kim Dae-Geon (9 July 1928)." (Kang 2016, pp. 570-71; emphasis added) $)^{16}$

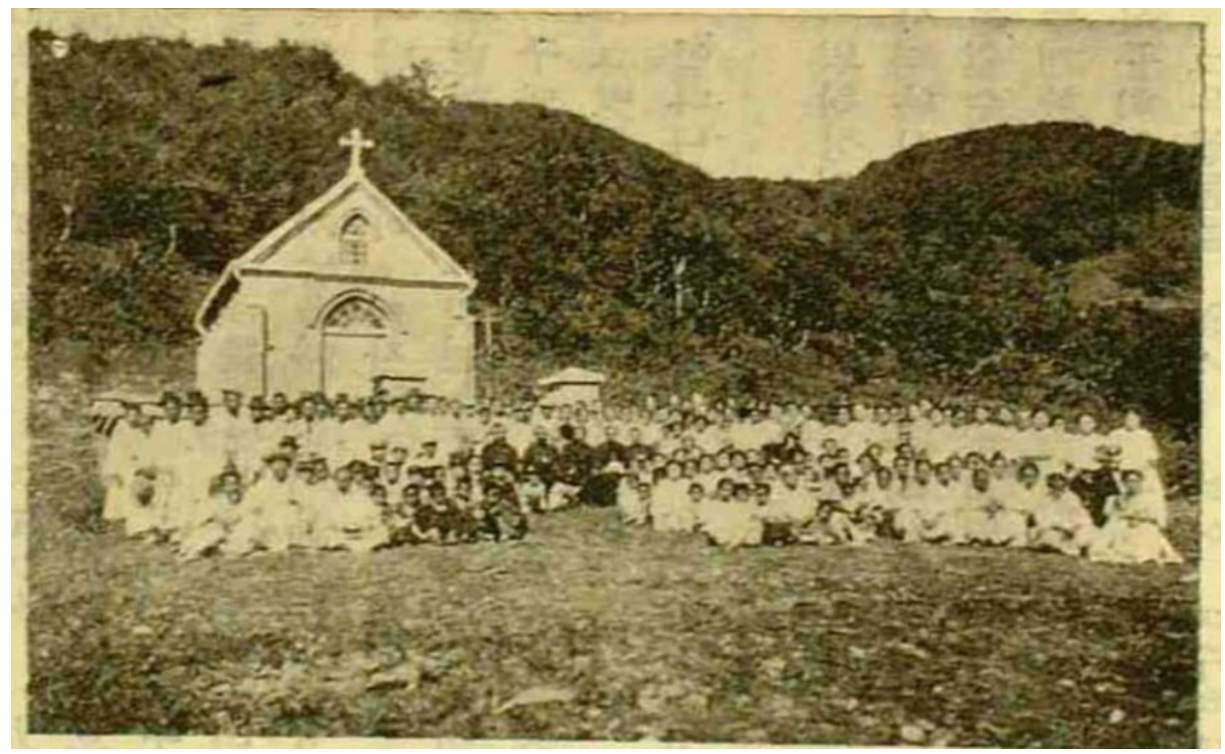

Figure 4. Image of the Memorial Church in 1932 [source: Catholic Youth, vol. 2, n. 9 (September 1934), p. 91]. 
When looking at the interior composition of the church, we observe a cross, a tabernacle where the sacrament is stored, a stone table enshrining the martyr's remains, an altar stone, and the altar where mass is held (see Figure 5). It is a small oratorium equipped with the basic shape of a Catholic church where mass can be held and dedication is performed. Looking at the plane, we see that the ambulatory at the altar stone of the church is bent at three angles (see Figure 6). There are three windows on each side inside the church and also three windows adjacent to the ambulatory. Light enters the church through nine windows.

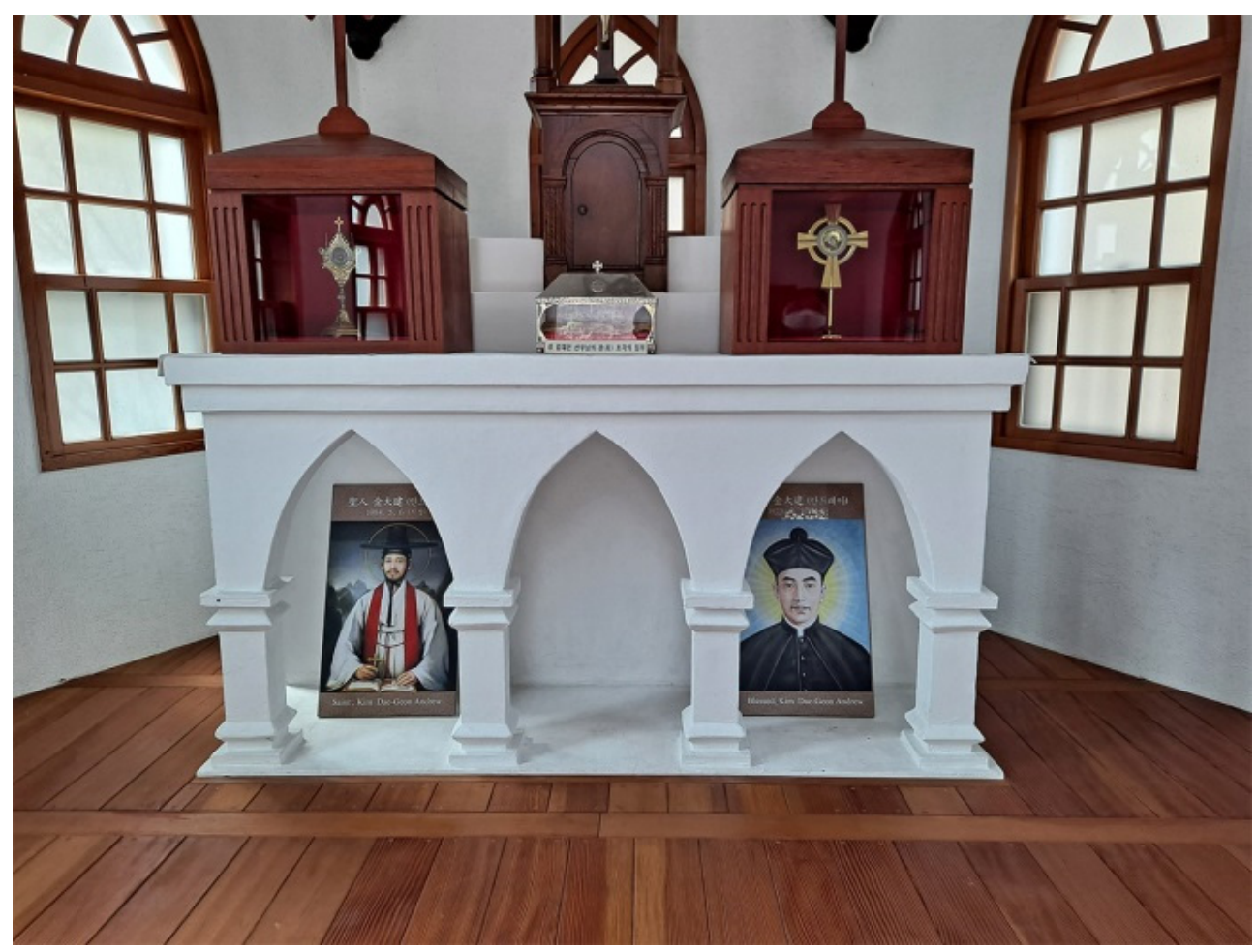

Figure 5. The interior of the Memorial Church in 2021 [source: photo by author].

In terms of architectural style, the important factor enabling one to classify the Memorial Church generally as of the Gothic style is the upper pointed arch's opening at the door and windows. Specifically, in the image of the front entrance, the pediment's window is Gothic, as are the nine window openings, which determines the overall atmosphere of the church. However, a number of specific details of the building's design differ from the typical European Gothic style (Im 2011, pp. 230-52). For instance, in the interior space, semi-circular arches and vaults are used, not pointed arches. That is, the nave has a barrel vault which forms the arcade. The relatively lower ceiling and bright and warm interior space are closer to the Romanesque style. The flat buttress located on the left and right sides of the exterior of the building and at the rear wall can be the style widely used from the Romanesque to the Gothic style. The vault, arch, and rib are all semi-circular and have a human scale suitable for the small church (see Figure 7). The building does not display the verticality emphasized by the Gothic style, and the flying buttresses, which are often the chief feature of the high Gothic architectural style, are not used. ${ }^{17}$ 


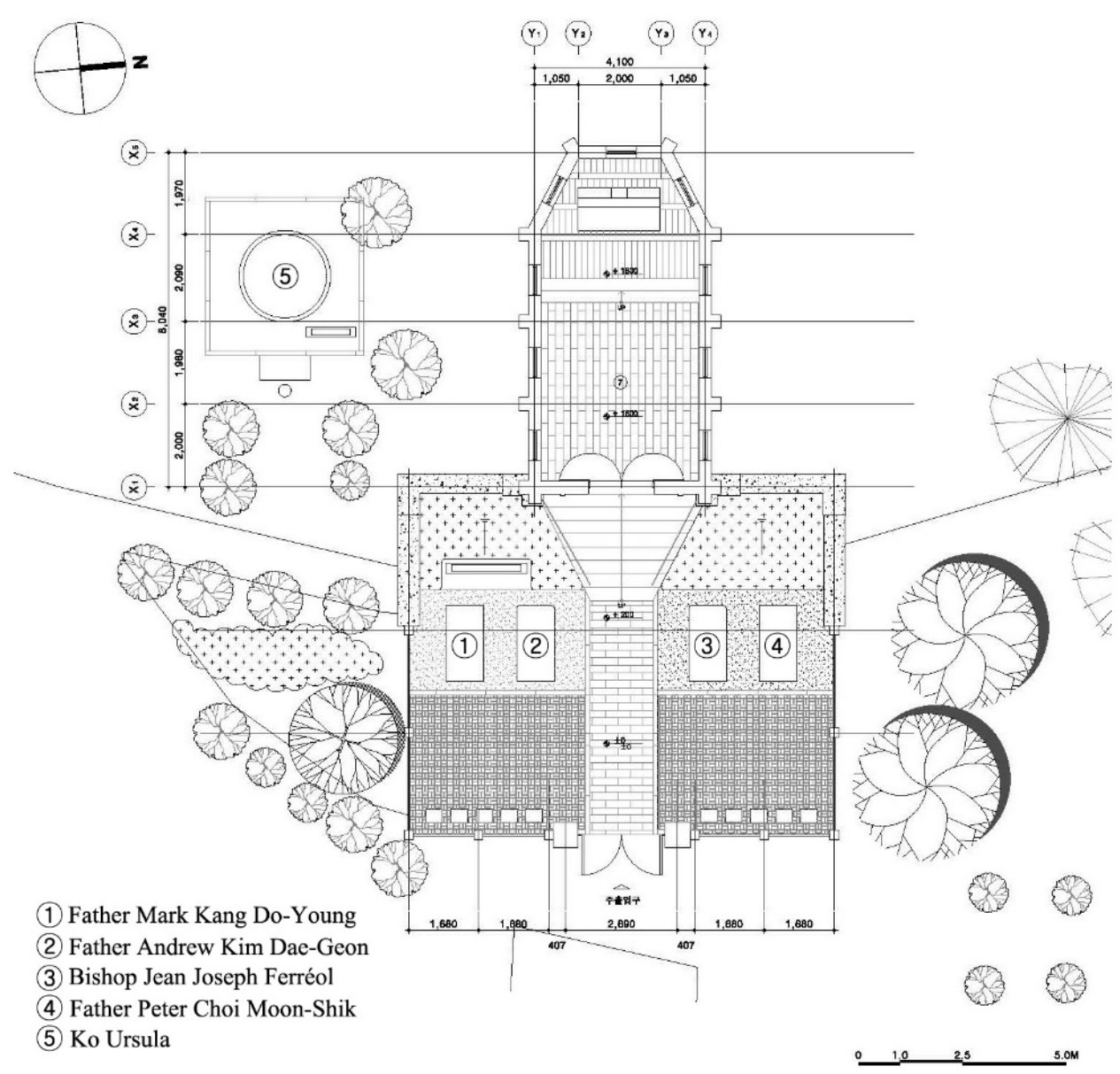

Figure 6. Floor and site plan of the Memorial Church [source: drawing by Heewoo Architecture and Conservation Architects. Co., Ltd.].

When comparing the Memorial Church with Jeondong Catholic Church (殿洞聖堂, 1908-1914) in Jeonju built by Father Victor Poisnel (1855-1925), slightly earlier than the Memorial Church, and despite having some difference in size, the architectural style of the Memorial Church can be ascertained (Kim 1984, pp. 24-28). ${ }^{18}$ The round-arched ceiling of the Memorial Church reminds visitors of Jeondong Catholic Church's interior (see Figure 8). The rib vault and dome inside the church is similar to the style used in the Jeondong Catholic Church. However, the ambulatory, the front inside of Jeondong Catholic Church, is bent at five angles, but the Memorial Church's ambulatory is bent at three angles. The difference may be derived from the difference in size between the two churches. Although the Memorial Church has a similar style to the Jeondong Catholic Church in various images, the former is a small, elegant, and humane scale church, compared to Jeondong Catholic Church, which uses a more grandiose version of the Romanesque style.

The primary building material of the Memorial Church is concrete, while the floor inside is made of wood. Although the rib vault used on the ceiling reminds visitors of the Romanesque, it, too is made of wood, not brick or stone. It seems to be used as a decoration rather than playing a structural role. The exterior buttress connected to the inner rib can also be regarded as decoration rather than serving the structural role of supporting the building's roof. 


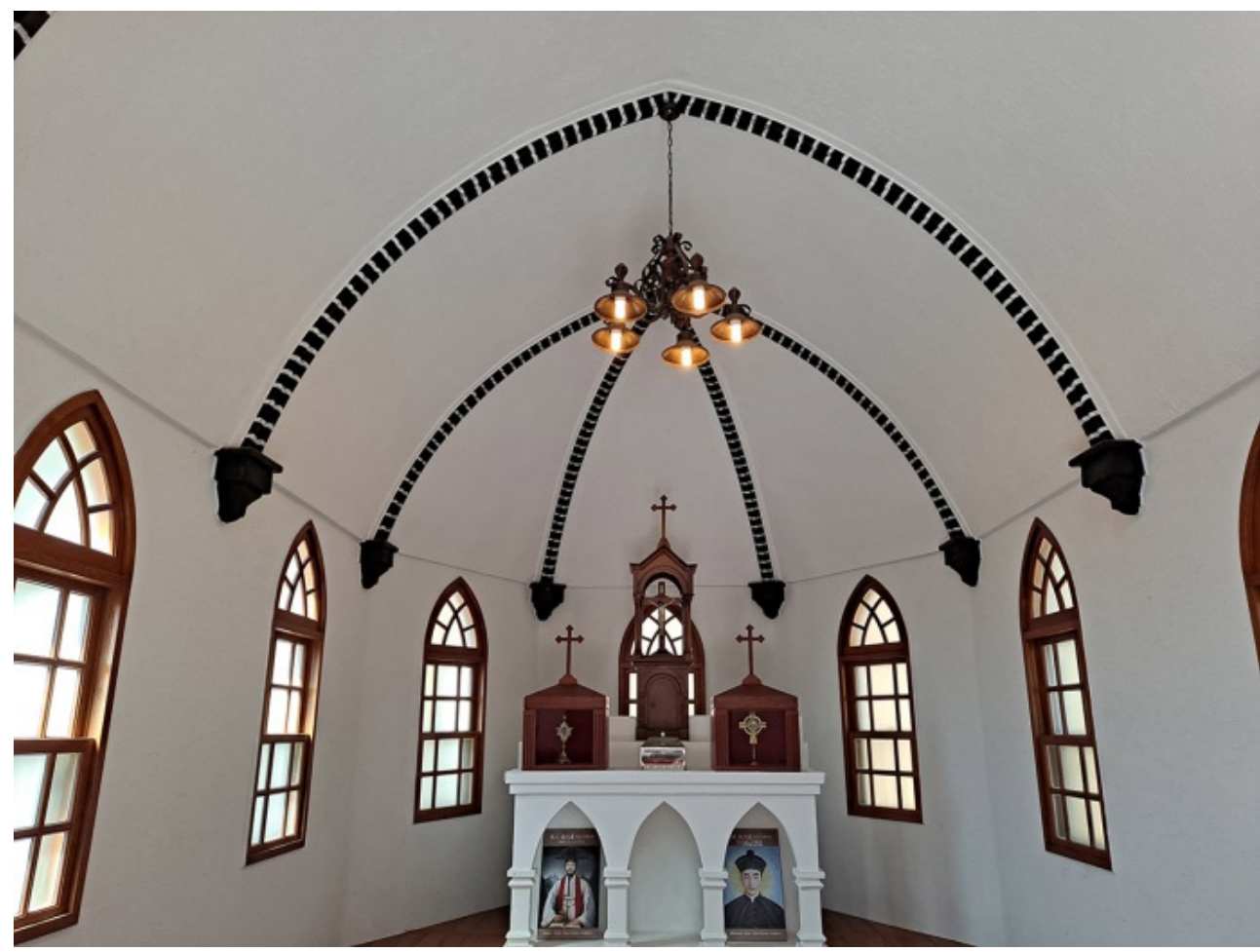

Figure 7. Interior image of the Memorial Church [source: photo by author].

In this sense, the Memorial Church is a Western-style cathedral built in the early modern period in the 1920s, showing a unique architectural style that mixes Romanesque and Gothic styles. Moreover, in terms of the architectural value of this building, different standards from large-scale cathedrals are needed, which are meaningful in that they attempted various Western architectural elements in small cathedrals built in the early 20th century.

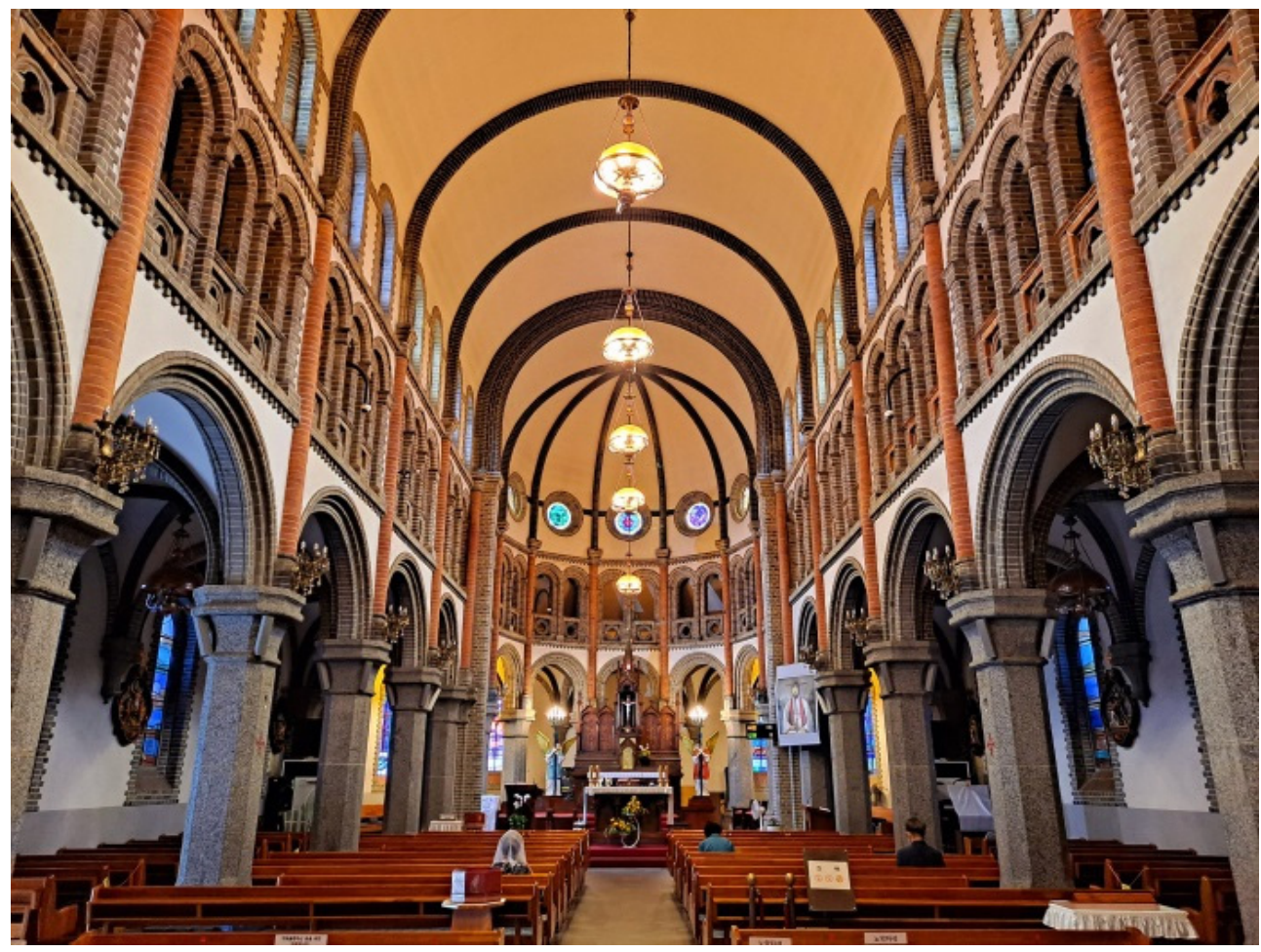

Figure 8. Interior image of Jeonju Jeondong Catholic Church [source: photo by author]. 


\subsection{Change Process and Preservation of the Memorial Church and the Surrounding Site}

\subsubsection{Changes to the Surrounding Site of the Memorial Church}

The Memorial Church built in 1928 and the surrounding site including Father Kim Dae-Geon's grave have undergone many changes from a usability aspect. This section traces the changes made to the church and the surrounding grave site, based on the archived photos. Examining by comparing the church and the surrounding site of the graves with the initial stage images may provide criteria for judging authenticity of the building and the surrounding site.

First, the front porch of the building is relatively new. Although there was no porch in the 1928 photo, there was a semi-circular white porch visible in the photos taken after 1976 (see Figures 9 and 10). At present, the porch is located at the entrance by shaping a gabled roof. The porch seems to have been added to prevent light from coming into the church, as it has an awning and is different form the building's architectural style.

Second, the material of the gabled roof has changed. The roof material of the initial stage is not known for certain. However, it was confirmed that galvanized sheet steel was used for the church roof, as seen in photos taken in 1965 and 1966 (see Figure 11). Galvanized steel sheet metal was widely used in modern buildings built in Korea before and after the 1930s. Therefore, there is a possibility that sheet steel had been used initially. At present, Spanish roof tiles are used (see Figure 12).

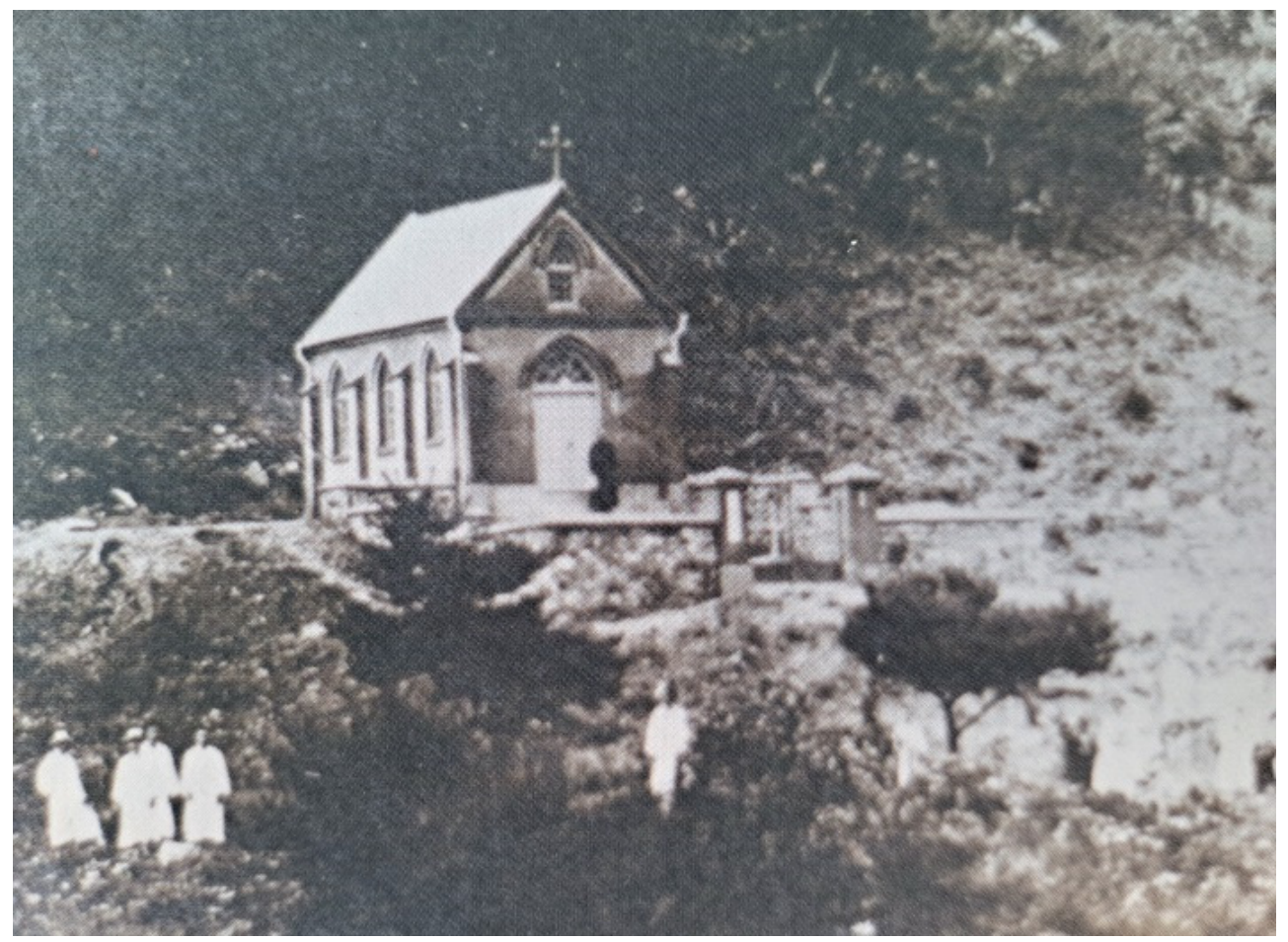

Figure 9. Image in 1928 [source: Father Mark Kang Do-Young's Collection of Letters, p. 568]. 


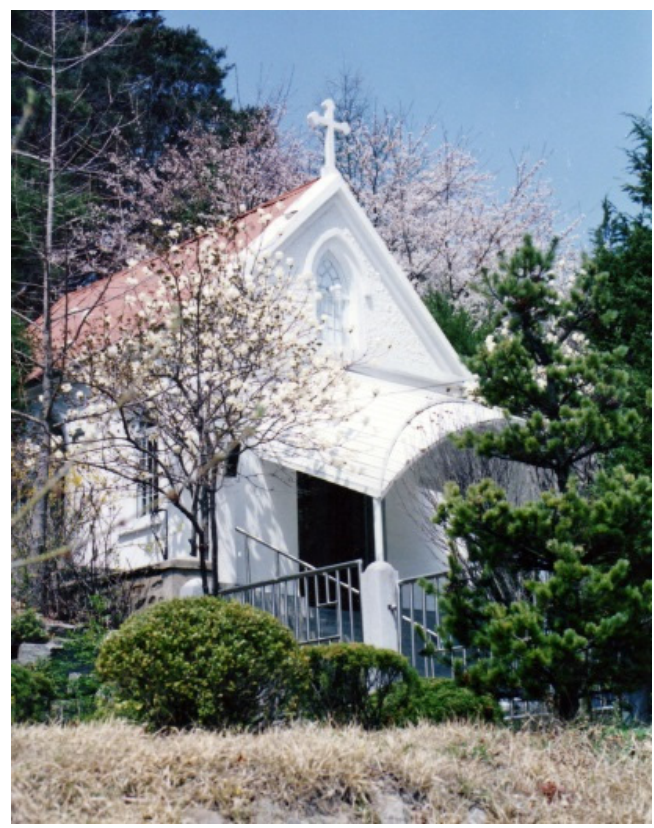

Figure 10. Image dated 26 September 1976 [source: courtesy of Mirinae Church].

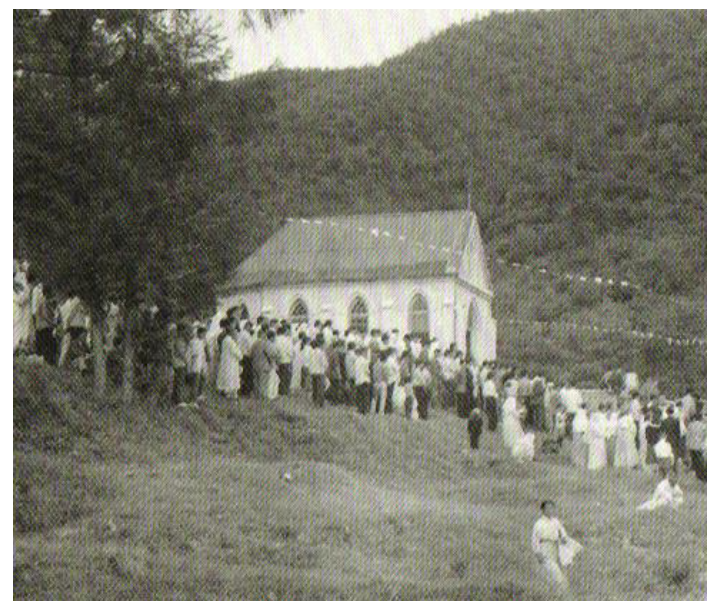

Figure 11. Image dated 26 September 1965 [source: Father Mark Kang Do-Young's Collection of Letters, p. 581].

Third, the stone wall around the graves in front of the building was removed. When looking at the initial photos of 1928 and record (Supplementum Tabella SS. Cordis Jesu), the approximately two-meter-high wall was built around the graves to mark the boundary (see Figure 13) (Guinand 1928). In a photo in 1965, the wall was still visible (see Figure 14). However, the south and west and east walls around the graves have disappeared and only the steel structure marking the boundary remains. 


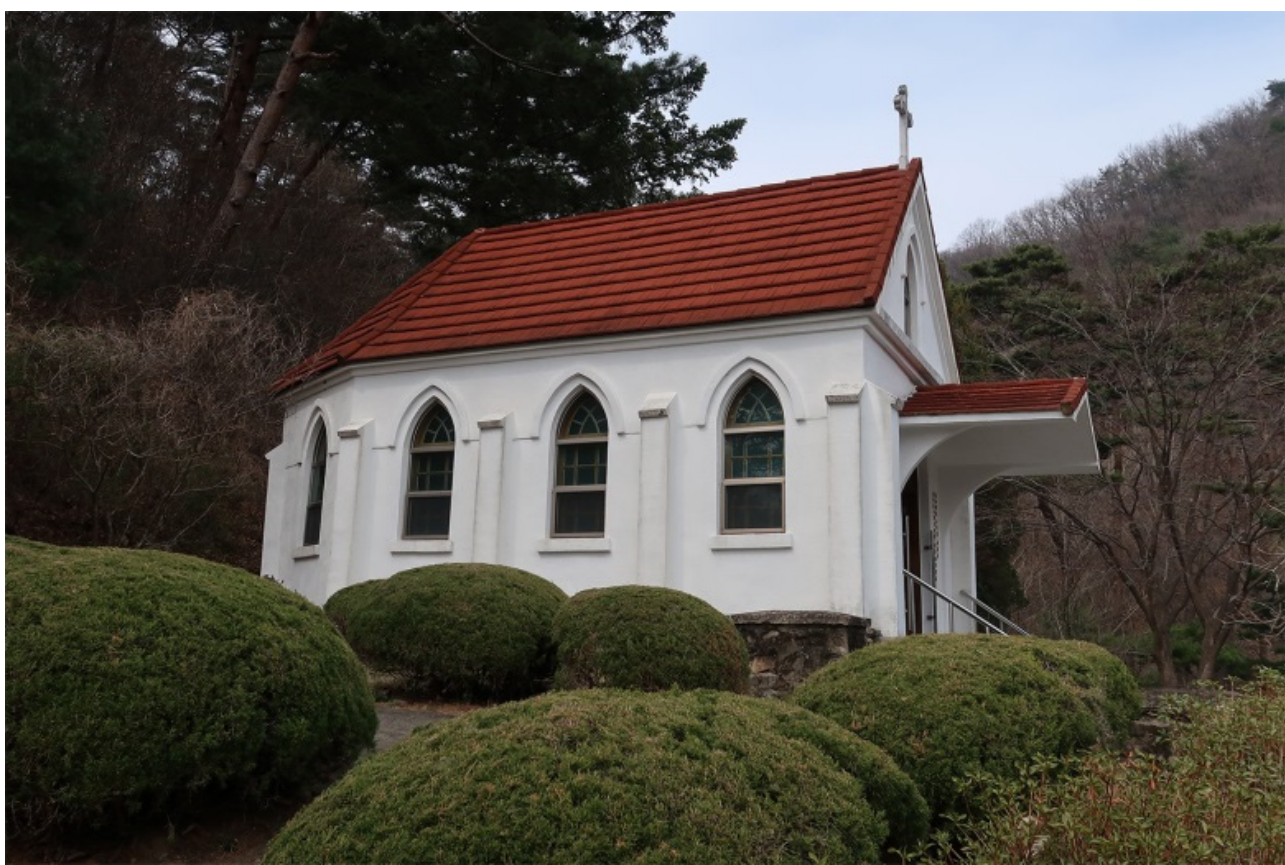

Figure 12. The roof material image of the Memorial Church in 2021 [source: photo by author].

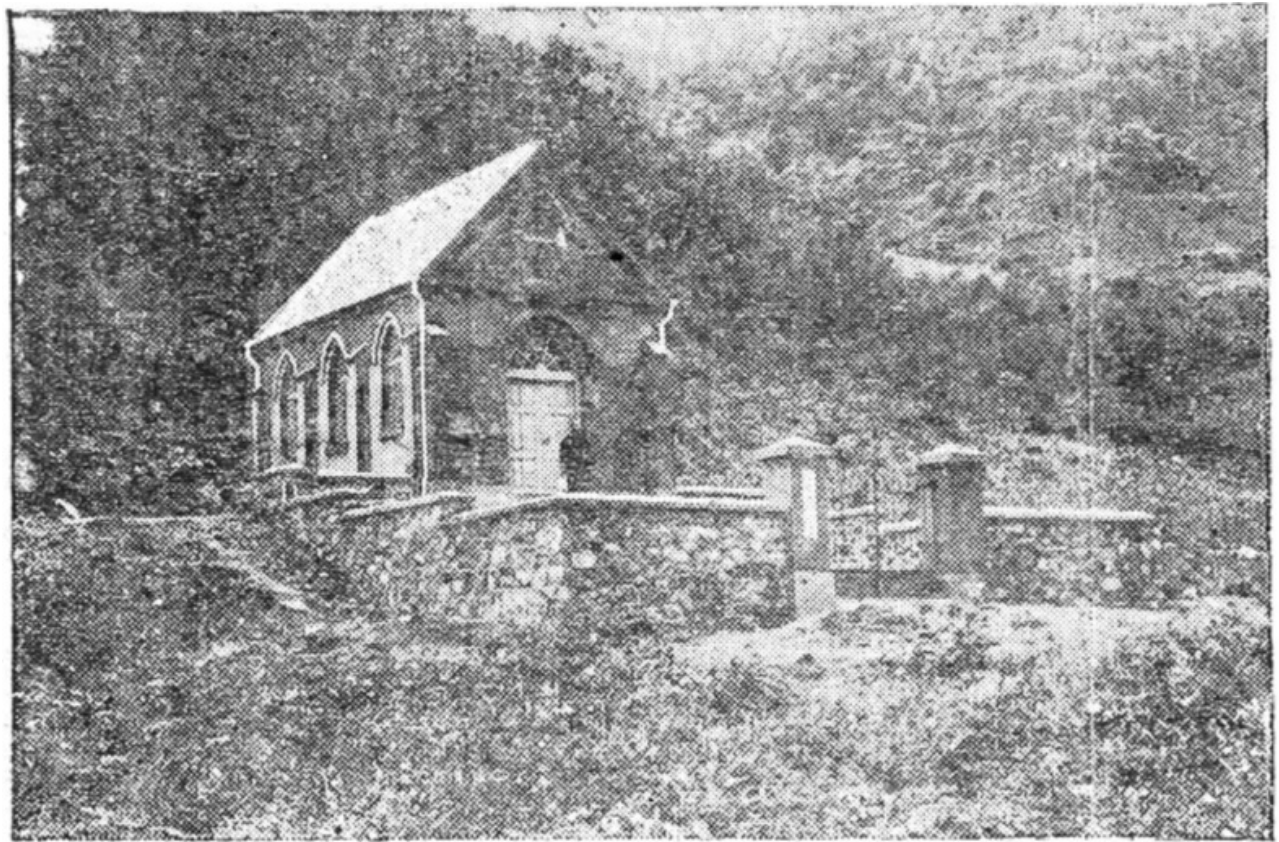

Figure 13. Image dated 1928 [source: The Dong-A Ilbo, 5 October 1928].

Fourth, the grave of Father Kim Dae-Geon has changed. The grave and the other graves in 1928 were made with concrete (Kang 2016, pp. 570-71). From the photos in 1965, 1970, and 1976, a cross on the concrete coffin shape can be seen (see Figure 15). However, a stone coffin replaced the concrete coffin in 1984 and information that the grave is Father Kim Dae-Geon's is inscribed on the black slab along with important dates (born: 21 August 1821; ordained: 17 August 1845; martyred: 16 September 1846; beatified: 5 July 1925; canonized: 6 May 1984) (see Figure 16). 


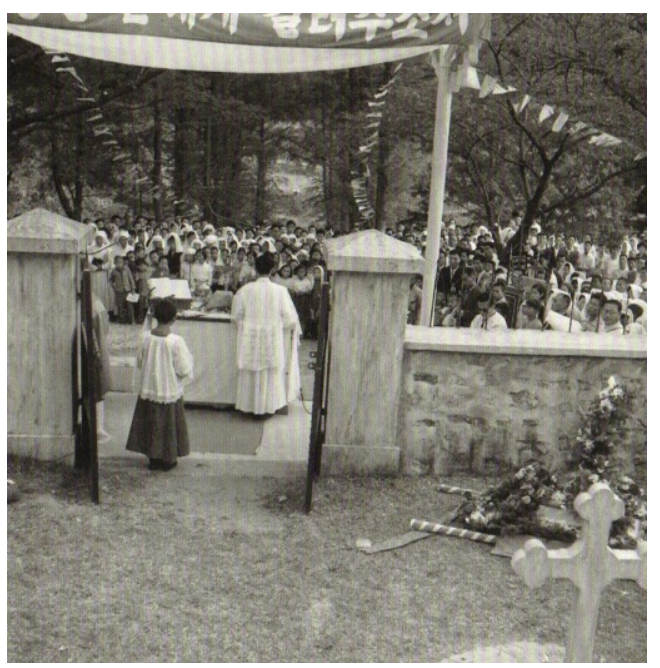

Figure 14. Image dated 26 September 1965 [source: Father Mark Kang Do-Young's Collection of Letters, p. 578].

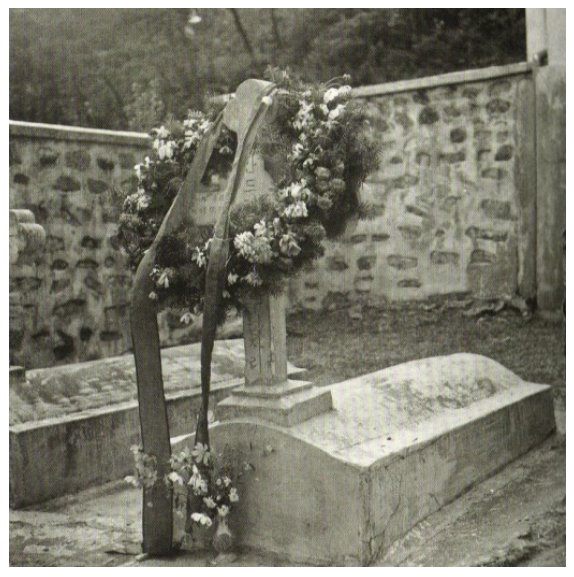

Figure 15. Graves of Father Kang Do-Young and Father Kim Dae-Geon; image dated September 1965 [source: Father Mark Kang Do-Young's Collection of Letters, p. 584].

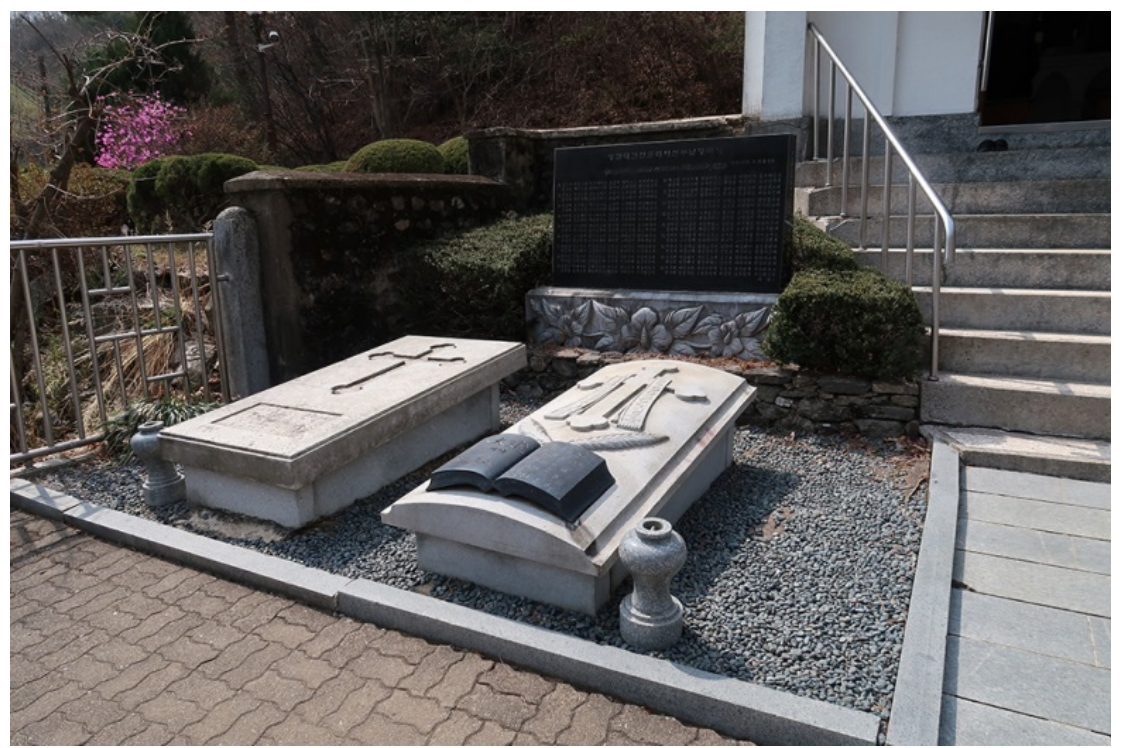

Figure 16. Graves of Father Kang Do-Young and Father Kim Dae-Geon; image dated April 2021 [source: photo by author]. 


\subsubsection{Evaluation of Value of Preserving the Memorial Church}

There are no clear criteria to use when selecting buildings as being of historical and cultural importance. Value evaluation is an issue of the evaluator's choosing, but philosophical deliberation is necessary for rational judgment in the process (Lee 2018, p. 87).

Although the church's architectural value has been discussed for a long time, the first document in which this was discussed was the Venice Charter in 1964. In Articles 9 and 13 of the Charter, aesthetic, historical, and archaeological values are listed, and the chronological aspects containing temporal traces or use value through utilization are also regarded as constituting architectural heritage (ICOMOS 1964).

To look at the value in preserving the Memorial Church and grave site, there is a need to examine its value based on the World Heritage Registration and Protection System used by the UNESCO Convention (World Heritage) in 1972 (UNESCO). To be registered as a World Heritage site, it should have outstanding universal value (OUV). ${ }^{19}$ The quality of heritage, which represents outstanding universal value, can be judged in terms of authenticity and integrity (Stovel 2007, p. 21).

To say that a cultural asset has authenticity means that it has original value in the heritage's material and technique. ${ }^{20}$ UNESCO evaluates the authenticity of a cultural asset according to six cultural criteria and judges the outstanding universal value of heritage. ${ }^{21}$ Further, integrity of cultural heritage means that there are various factors that suffice to show the asset possesses heritage value. ${ }^{22}$ That is, it has outstanding universal value that is sustained over time. If a cultural asset is to maintain authenticity, it also should have integrity which shows the heritage's value sufficiently.

"Authenticity", as used in the World Heritage registry, is a concept differentiated from the original form of the cultural asset. However, it is in a very similar position in relation to value, which is the most important attribute of architectural heritage. Authenticity is regarded as a site's ability to represent the value and the original form is regarded as a critical factor shaping and embodying the value in Korea. In this respect, authenticity can play a similar role for architectural heritage to determine its value (Lee 2017, p. 67).

Examining the value of the Memorial Church may offer a standard to justify continuing to preserve and manage the building and the surrounding site. From the perspective of authenticity in the architectural value of the Memorial Church, the exterior materials and structure of the Memorial Church maintain the original form. The present appearance of the church in 2021 can be compared with that pictured in an article by The Dong- $A$ Ilbo written in 1928. The exterior window shape and that of the structure is the same as in those days. From a functional aspect, it was found that a porch was added, and roof materials were changed to be suitable for modern use. However original architectural materials or techniques have been maintained. From the perspective of integrity, the value of Father Kim Dae-Geon's grave site is essential. As for the site around the grave in the Mirinae Shine, the church is the building built around the grave where his remains were collected and buried in Mirinae for the first time. Because he was Korea's first priest, it is a meaningful site having historical significance in Korean Catholic history; it played a pivotal role for the belief community of Mirinae, and it is a venue that pilgrims continuously visit even today. From such a perspective, it is a space where integrity is embodied, enabling universal value to be sustained.

\section{Sense of Place (or Genius Loci) of the Memorial Church and the Surrounding Grave Site}

A place means a venue where something happens. A building is built based on the purpose of the place, and the building's meaning can be more remarkably revealed through its relations with the place. All places have their own features, and they are called the sense of place. The sense of place, or genius loci, refers to the particular, unique nature that a place has and how it is revealed through its physical features, and images and people's activities based on them (Relph 1976, pp. 103, 114, 290). Essentially, the sense of place can be formed through cognitive activities revealed through various activities of the players using the space in the place (Uhr and Yuh 2010, pp. 21-34). 
"We should therefore have to say how we inhabit our vital space, in accord with all the dialectics of life, how we take root, day after day, in a "corner of the world." (Bachelard 1994, p. 4)

A French philosopher and poet Gaston Bachelard (1884-1962) deals the phenomenology of residential space in his book The Poetics of Space (Bachelard 1994, pp. 3-37). In this book, he explains how the experiences of home in childhood can shape the rest of a person's life (Bachelard 1994, p. 4). It is said that the living space is, above all, a vessel that contains our thoughts. As a space forms the character of sense of place through conversations with the thoughts of the person staying in the space, it can be said that the activities of a person experiencing the space play an important role in determining the characteristics of the space. In the sense, this can be seen as sharing its meaning with Martin Heidegger's poetic dwelling (Heidegger 1977, p. 340; Seo 2014, p. 136).

American philosopher and educator Susanne Katherina Langer (1895-1985) emphasized the fact that architecture visualizes a place's features, and Canadian geographer Edward Relph (1944-) states that a place is the environment containing fully meaningful human intentions (Relph 1976, pp. 103, 114, 290). According to Relph, the definition of a place should include the intentions of the structure composed of humans' consciousness and experiences (Relph 1976, pp. 103, 114, 290). British architect Matthew Carmona stresses that place identity is important among the various factors forming the sense of place (Carmona et al. 2010, pp. 120-23). Geographer Fred E. Lukermann represented the characteristic of place as a significant component of architectural reinterpretation. According to Lukermann, components that shape the sense of place in architecture include location, integration of natural and cultural factors, place connectivity, place locality, the organic attributes of place, and the meaning of place (Lukermann 1964, pp. 167-72). Historian Pierre Nora argues that the memories reproduced and actualized as continued peoples act for a long time in a specific place become another history using the concept of sites of memory (Les Lieux de Mémoire) (Nora 1989, pp. 7-24). Based on their theories, the value of the sense of place for the site around Father Kim Dae-Geon's grave can be conceptualized as follows:

First, value comes from a differentiation from other places. The sense of place where a building is placed gains this through various influences such as landmarks and visual beauty. In terms of the building's physical setting, the Memorial Church is located on the slope of the northern part and the deepest palace within the Mirinae Shrine. Therefore, it plays a symbolic role as a landmark. From an architectural perspective, the church possesses aesthetic beauty through the harmony of its white walls and red roof, and formal differentiation from other buildings in the shrine complex. The Memorial Church and the grave site differ from other Catholic Church places because these two different aspects (the memorial church and the grave) co-exist in one place.

Second, value is connected history. This is meaningful because the buildings preserve or reinterpret the sense of history that existing places have. The space of Mirinae is the place where believers' village existed in which believers gathered and lived to escape from Byeongoh Persecution in 1846 (Kang 2016, p. 4). The Memorial Church was built where Father Kim Dae-Geon's remains were buried. The place therefore has huge historical meaning in modern Korean history beyond the church history of Korean Catholicism and is the place that preserves it.

Third, the Memorial Church has creative value as a site of human acts and memory. The Memorial Church and the surrounding grave site are the space where the pilgrims' migration path culminates in the Mirinae Shrine. The space plays a role as the place of rest through the sense of pilgrimage for those who visit the space. In 1965, as the graves of Ko Ursula and Vincentius Lee Min-Shik were relocated to the present location from the location below the grave of Father Kim Dae-Geon, a small plaza was shaped there. The martyr exaltation convention has been held by the parish there since 1964 and it became an annual event (see Figure 17) (Gyeonghyang Magazine 1964, p. 555). A place for acts was prepared, as human acts were added, and so the meaning as a shrine is continuously 
created. The space's historical meaning still continues to the present as a historic site of Catholic pilgrimage (see Figure 18).

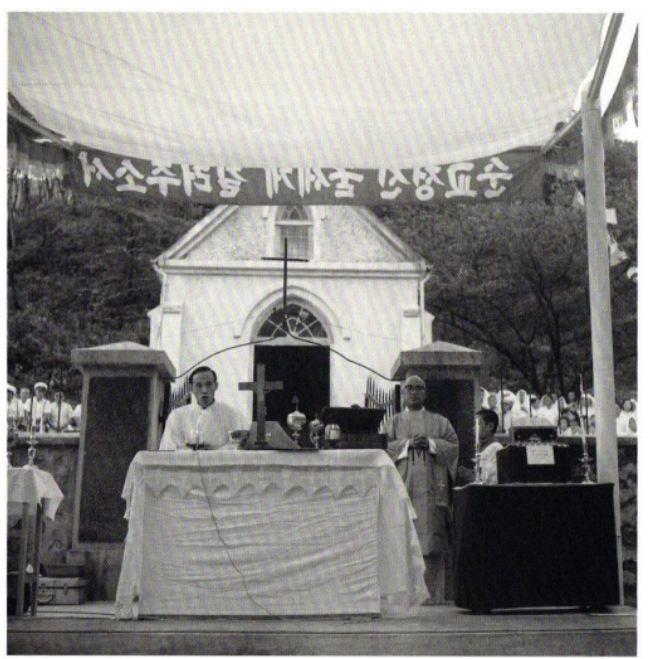

Figure 17. Image of dedication Mass in front of the Memorial Church in 1965 [source: Father Kang Do-Young's Collection of Letters, p. 579].

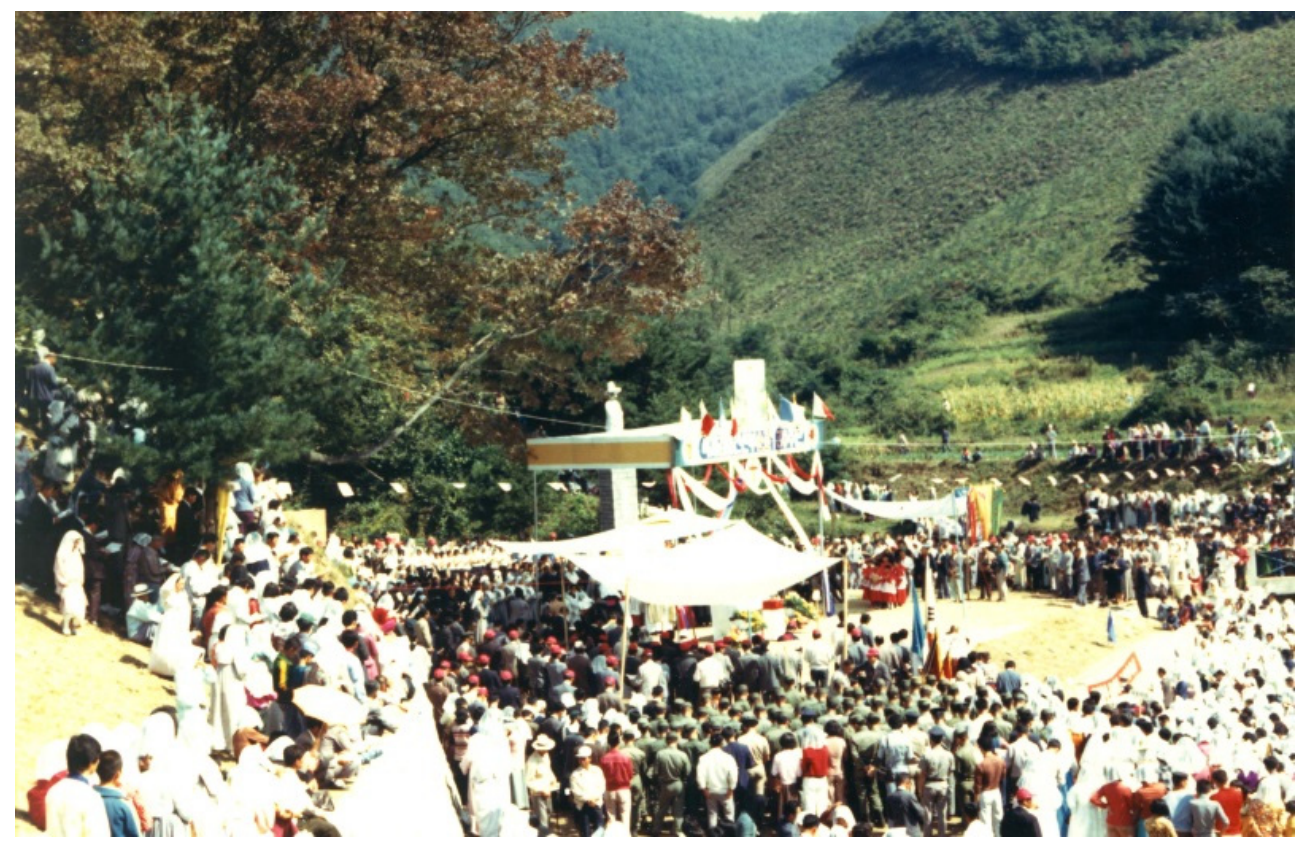

Figure 18. The 130th Anniversary of the Blessed Exaltation Convention on 26 September 1976 [source: courtesy of Mirinae Church].

\section{Conclusions}

The value of the Memorial Church and the surrounding site of Father Kim Dae-Geon's grave has various meanings difficult to define in terms of just one concept. The importance and meaning can be explained as follows:

First, the Mirinae Shrine is not only the place where the grave of Korea's first MartyrPriest Kim Dae-Geon is located but is also the burial site of other people who played pivotal roles in the process of establishing Korean Catholicism. The Memorial Church itself is the specific site where Father Kim Dae-Geon's body was collected and buried. Thus, the church and the surrounding grave site have been recognized as a place of pilgrimage and they became the starting point for the present Mirinae Shrine to be continuously maintained. 
Second, the Memorial Church is a Western-style church built in the early Korean modern architectural style of the 1920s and shows a unique architectural style mixing Romanesque and Gothic. Moreover, because the Memorial Church and graves co-exist in the same space, it is different from other oratoria. From an architectural perspective, it has a meaning from the standpoint that this small church incorporates various Western design influences. The Memorial Church's original form has been preserved relatively well for nearly 100 years since it was built; therefore, it has significant historical value in terms of authenticity and integrity.

Third, the Memorial Church and the surrounding grave site become the culmination of the pilgrims' migration path in the Mirinae Shrine and provide a space of rest for those who visit the place. The space is meaningful as the venue where Catholic believers regularly gather formally in such events as the annual pilgrims' exaltation convention. This continues as a historic site of Catholic pilgrimage without interruption of the meaning in combination of the acts happening in the venue with a historical meaning beyond the physical space as a shrine. The venue has important significance as a memorial site for those who shared the experiences represented there.

The Memorial Church and the surrounding grave site, where part of Father Kim Dae-Geon's remains are buried, not only play a role as a key venue in Catholic Church history, but the venue has great meaning in terms of architectural history. There is a need for the venue to be continuously preserved and managed as a meaningful place in Korean church history, beyond just the Catholic and local communities.

Funding: This work was supported by the National Research Foundation of Korea (NRF) grant funded by the Korea government (MSIT) (No. 2020R1G1A1011806).

Acknowledgments: A part of this research was presented at the Colloquium for a registered cultural heritage of the Mirinae Shrine in April 2021.

Conflicts of Interest: The authors declare no conflict of interest.

\section{Notes}

1 Gongso (公所, Small Catholic Church) is a Catholic place of worship smaller than a parish church. It is a gathering of local believers where the provost does not reside. As a priest does not reside there, mass is not held; instead, a service is held in which offertory is omitted, centered on the head of the Catholic church who acts for the parish church priest.

2 Mirinae means "The milky way is flowing under the moonlight" in Korean, and it was called Mirinae because the light under the moonlight looks similar to the Milky Way. During the Catholic Persecution of 1801 (Shinyu) and 1839 (Gihae), Catholic believers came and hid there. They were scattered widely, living by carving vessels and clearing fields.

3 Beatification is the Pope's declaration allowing the title of the Blessed for a reputed person due to martyrdom.

4 On 2 November 2020, the name of "Memorial Oratory for 79 Blessed Korean Martyrs" within Mirinae Shrine in Anseong was changed to the "St. Andrew Kim Dae-Geon Memorial Church" in the Suwon Catholic parish.

5 The rest of the remains were buried in Daeshin Seminary in Hyehwa-dong and then were relocated to the Jeoldusan Martyrs' Memorial Hall.

6 There are pastoral letters including "Bishop Mütel's Diary”, letters of Bishop Mütel during his priest period and a collection of letters of Father Mark Kang Do-Young.

$7 \quad$ Name or title are exalted in the world.

8 "Oratory", Merriam-Webster, https:/ / www.merriam-webster.com/dictionary/oratory, accessed 3 April 2021.

9 In general, the oratorium of bishops is regarded as oratorium semi-publicum.

10 Article 1188.2 of the Church Code in 1917.

11 Original text: see 5-9 May 1921 and 15-22 May 1922of Bishop Mütel's diary for the date of Korean priests' retreat date during 1921 and 1922.

12 Original text: Mütel Document 1922-1975, Father Kang Do-Young's letter dated 30 May 1922. The underlines in the quotation in the statement were made by the author of this paper to emphasize.

13 The author arranged the details by adding some more, centered on Chapter 3, the St. Adrew Kim Dae-Geon and Mirinai Memorial Oratorium History_-“Memorial Church Mirinai Shrine, Father Kim Dae-Geon's Grave, and Mirinai Church", drawn up by Cha Gi-Jin in the Cultural Asset Registration Application Form drawn up in 2009. 
http:/ /encykorea.aks.ac.kr/Contents/Item/E0076853, accessed on 10 May 2021.

16 Originally quoted in Tabella Supplementum Tabella SS. Cordis Jesu n. 34 (20 October 1928).

17 Although the Memorial Church is broadly classified as Gothic style according to existing research, in my opinion, the church should be seen as the mixture of Gothic and Romanesque styles.

18 For the initial research on the Jeondong Catholic Church, please see the following research: Jung-Shin Kim, "Jeondong Catholic Church", Monthly Architecture and Culture n. 40 (September 1984): 24-28.

Based on "The Criteria for Selection" with the UNESCO World Heritage, http:/ / whc.unesco.org/en/criteria/, accessed 2 April 2021. See above the Criteria for Selection with the UNESCO World Heritage.

21 The factors determining authenticity are the following six and each factor consists of a pair of two items: form and design, material and substance, location and setting, use and function, tradition and technique, and spirt and feeling.

\section{References}

Bachelard, Gaston. 1994. The Poetics of Space. Translated by Maria Jolas, with a new foreword by John R. Stilgoe. Boston: Beacon Press.

Baek, Chang-Hyun. 2020. The Name of Memorial Cathedral for Beatification in Mirinae, Anseong will be Changed to the St. Andrew Kim Dae-Geon Memorial Church. Joongbu Ilbo. (3 November 2020). Available online: http:/ / prt.joongboo.com/news/articleView. html?idxno=363453787 (accessed on 28 March 2020).

Carmona, Matthew, Tim Heath, Taner Oc, and Steven Tiesdel. 2010. Public Places-Urban Spaces. London: Taylor \& Francis Group.

Catholic Bishops' Conference of Korea. 1927. Construction of Monument in the Relocated Grave of the Blessed St. Andrew Kim Dae-Geon. Gyeonghyang Magazine, May 15.

Catholic Suwon Parish Maintenance Foundation. 2009. Cultural Asset Registration Application Form. Suwon: Catholic Suwon Parish Maintenance Foundation.

Cha, Gi-Jin. 2008. Father Mark Kang, Do-yeong (1863-1929) and his Celebrating Movement for St. Andrew Kim, Dae-geon. Research Journal of Catholic Church History 5: 209-34.

Dallet, Claude-Charles. 1980. The History of Korean Catholic Church (Histoire de l'Eglise de Corée) Part 2. Translated by Eung-Ryul Ahn, and Seok-Woo Choi. Seoul: The Research Foundation of Korean Church History.

Kang, Do-Young. 2016. Father Mark Kang Do-Young's Collection of Letters. Edited by Seung-Ryong Choi. Seoul: The Research Foundation of Korean Church History.

Guinand, Antoine Louis. 1928. Tabella Supplementum Tabella SS. Cordis Jesu 34. (20 October 1928).

Catholic Parish of Suwon- Great Success of the Pilgrimage. Gyeonghyang Magazine 1160: 555, (1 November 1964).

Heidegger, Martin. 1977. The Question Concerning Technology. In Basic Writings. New York: Harper \& Row, pp. 307-41.

ICOMOS. 1964. The Venice Charter: International Charter for the Conservation and Restoration of Monuments and Sites. Paris: ICOMOS.

Im, Seok-Ja. 2011. The History of Western Architecture. Seoul: Bookhouse.

Jung, Ja-Yeon. St. Andrew Kim Dae-Geon Memorial Church in Mirinae Shrine of Anseong Regained its Original Name. Kyeonggi Ilbo, 3 November 2020. Available online: https:/ / www.kyeonggi.com/news/articleView.html?idxno=2326314 (accessed on 2 April 2021).

Jung, Jong-Deuk. 2008. The Historical Significance of Mirinae Shrine. Research Journal of Catholic Church History 5: 7-46.

Kim, Jung-Shin. 1984. Jeondong Catholic Church. Monthly Architecture and Culture 40: 24-28.

Lee, Seok-Won. 2008. The Change and Historical Meaning of Mirinae Parish; Especially in the Changing Aspects of his Religious Influence and of Catholic Communities Kong-so. Research Journal of Catholic Church History 5: 235-82.

Lee, Seung-Hoon. 2020. Change of the Name from Memorial Oratory for 79 Blessed Korean Martyrs. Catholic Times, November 8. Available online: https:/ / m.catholictimes.org/mobile/article_view.php?aid=349079\&params=page\%3D1\%26acid\%3D1\%26top\% 3D1 (accessed on 1 April 2021).

Lee, Su-Jung. 2017. Conservation Ethics. Seoul: Graphickorea.

Lee, Su-Jung. 2018. Conservation Philosophy. Review of Architecture and Building Science 57: 14-18.

Lukermann, Fred E. 1964. Geography as a Formal Intellectual Discipline and the Way in which it Contributes to Human Knowledge. Canadian Geographer 8: 167-72. [CrossRef]

Nora, Pierre. 1989. Between Memory and History: Les Lieux de Mémoire. Representations 26: 7-24. [CrossRef]

Oh, Seok-Geun. 1961. The Life and Achievements of Korea's Third Father Kang Mal-Gu (Do-Young). Catholic Youth 15: 40-50.

Relph, Edward. 1976. Place and Placelessness. London: Pion.

Seo, Myengsoo. 2014. Cultural sustainability through architectural preservation: A case study of Frank Lloyd Wright's Florida Southern College. International Journal of Sustainable Building Technology and Urban Development 5: 135-42. [CrossRef]

Stovel, Herb. 2007. Effective Use of Authenticity and Integrity as World Heritage Qualifying Conditions. City \& Time 2: 21-36.

Suwon Research Institute of Catholic History. 2017. 50 Years of History of Suwon Parish: 1963-2013 I. History of Parish. Suwon: Catholic Parish of Suwon.

The Dong-A Ilbo. 1928. St. Andrew Kim Dae-Geon Memorial Church. The Dong-A Ilbo, October 5.

Uhr, Jeong-Yeun, and Hong-Koo Yuh. 2010. A Study on Place Value on the Notion Place. Korea Planning Association 4: 21-34.

UNESCO. The Criteria for Selection. Available online: http:/ / whc.unesco.org/en/criteria/ (accessed on 2 April 2021). 